\section{Thomas Goda}

Universidad EAFIT

Medellín, Colombia

Recibido: 15 de junio de 2016

Concepto de evaluación: 18 de octubre de 2016

Aprobado: 20 de octubre de 2016

Artículo de investigación (C) 2017 Universidad Católica de Colombia. Facultad de Ciencias Económicas y Administrativas. Todos los derechos reservados

* PhD in Economics. Assistant Professor at the Universidad EAFIT, School of Economics and Finances, Medellín, Colombia. Mailing address: Carrera 49 No. 7 Sur-50, Medellín, Colombia. Email: tgoda@eafit.edu.co

\section{A comparative review of the} role of income inequality in economic crisis theories and its contribution to the financial crisis of 2007-2009*

\section{ABSTRACT}

It is widely accepted that inequality has increased sharply recently in developed countries, but no consensus exists so far about the importance of inequality in the financial crisis of 2007-2009. The aim of this article is to outline and contrast the theoretical underpinnings of Marxian, post-Keynesian, and mainstream crisis theories, and to compare their viewpoints regarding the role that income inequality played in the crisis. The results of this review suggest that, despite important differences in their theoretical concepts, several economists of these three strands offer a similar explanation on why income inequality was an important contributing factor to the financial crisis.

Keywords: income inequality, personal income distribution, crisis theories, financial crisis, schools of economic thought.

JEL: B0, D3, E25, G01

\section{Una revisión comparativa del papel de la desigualdad de ingresos en las teorías de la crisis económica y su contribución a la crisis financiera de 2007-2009}

\section{RESUMEN}

Es ampliamente aceptado que la desigualdad en los países desarrollados ha aumentado considerablemente en los años recientes, pero hasta el momento no hay consenso sobre la importancia de la desigualdad en la crisis financiera de 2007-2009. El objetivo de este artículo es esbozar y contrastar los fundamentos teóricos de las teorías de crisis marxista, poskeynesiana y convencional, y comparar sus puntos de vista sobre el papel que desempeñó la desigualdad de ingresos en la crisis. Los resultados de esta revisión sugieren que, a pesar de

\footnotetext{
* I am grateful to Photis Lysandrou, John Sedgwick, Humphrey Shaw, two anonymous referees, and the participants of the 1st World Keynes Conference in Izmir for their helpful comments.
} 
importantes diferencias en sus conceptos teóricos, varios economistas de las tres corrientes ofrecen una explicación similar de por qué la desigualdad de ingresos fue un factor importante que contribuyó a la crisis financiera.

Palabras clave: desigualdad de ingresos, distribución del ingreso personal, teorías de la crisis, crisis financiera, escuelas de pensamiento económico.

\section{Uma revisão comparativa do papel da desigualdade de renda nas teorias de crise econômica e sua contribuição para a crise financeira de 2007-2009}

\section{RESUMO}

É amplamente aceito que a desigualdade de renda nos países desenvolvidos tem aumentado de forma significativa nos últimos anos; contudo, até agora, não há um consenso sobre a importância dela na crise financeira global de 2007-2009. O objetivo deste artigo é esboçar e contrastar os fundamentos teóricos das teorias de crise marxista, poskeynesiana e convencional, e comparar seus pontos de vista sobre o papel que a desigualdade de renda desempenhou na crise. Os resultados desta revisão sugerem que, apesar de importantes diferenças em seus conceitos teóricos, vários economistas das três correntes oferecem uma explicação similar de por que a desigualdade de renda foi um fator importante que contribuiu para a crise financeira.

Palavras-chave: crise financeira, desigualdade de renda, distribuição da renda pessoal, escolas de pensamento econômico, teorias de crises. 


\section{INTRODUCTION}

Research on the impact of changes in the distribution of income has a long-standing history in the area of political economy. Specifically, Marx and Keynes stressed that high levels of inequality can not only have negative social effects, but can also destabilize the economic system. The topic of inequality fell somewhat out of fashion in the last quarter of the twentieth century (Atkinson, 1997), but it has since returned to the center of political and economic debates.

One reason for this 'revival' is the rise of both personal and functional income inequality over the past 35 years to levels not seen since World War II (Piketty, 2014; Stockhammer, 2015a; Goda, 2016). Functional income distribution distinguishes between production factors, i.e. it measures how much of the national income goes to workers (wage share) and how much of it goes to capitalists and rentiers (profit share). In contrast, personal income distribution measures how far national income is equally distributed among individuals/ households.

Another reason why this topic is getting increasingly more attention is that several authors have suggested that the increase in income inequality was an important contributing factor to the recent financial crisis that began in the market for subprime derivatives (e.g. Foster \& Magdoff, 2009; Rajan, 2010; Stiglitz, 2012; van Treeck, 2014; Stockhammer, 2015b, Kumhof et al., 2015). However, this has remained a minority view to date. Studies about the crisis have mainly focused on the regulation of global financial markets (Davies, 2010; Major, 2012; Boyer, 2012; Vázquez \& Federico, 2015), Minskian instability (Wray, 2009; Dymski, 2010; Vercelli, 2011; Sau, 2013), monetary policy (Taylor, 2009; Morgan, 2009), market failures (Ashcraft \& Schuermann, 2008), and irrational behavior (Akerlof \& Shiller, 2009).

This article first summarizes the crisis theories of different schools of thought and the role that income inequality plays in these theories, before it compares the main arguments of those economists who have argued that the recent financial crisis was caused by an increase in income inequality. This comparative review does not intend to provide a detailed review of all existing crisis theories, but instead aims (i) to outline the main underpinnings of some important crisis theories, and (ii) to establish whether, according to existing literature, inequality can be seen as an important factor behind the financial crisis of 2007-2009.

Due to space limitations, focus will be given to the two economic schools that most extensively have discussed the relation between income inequality and crises-Marxism and post-Keynesianism-and the two dominant contemporary economic schools-neo-classical economics and new-Keynesianism. ${ }^{2}$ The author is aware of the fact that it is not possible to make a sharp distinction between Marxian and post-Keynesian approaches. However, given that there do exist important differences between Marxian and post-Keynesian crisis theories, these two schools are discussed separately. On the contrary, the two dominant contemporary schools of thought are discussed under the heading 'mainstream economics' on the grounds that their essential features are very similar.

This paper has the following structure. Section two reviews the role of income inequality in Marxian crisis theories. Section three reviews the role of income inequality in post-Keynesian crisis theories. Section four reviews the role of income inequality in mainstream crisis theories. Section five presents the conclusions.

\section{MARXIAN CRISIS THEORIES AND THE ROLE OF INCOME INEQUALITY}

\section{Marxian theories of crisis: An overview}

All Marxian crisis theories rest on the assumptions that, in a capitalist system, (i) profit is the

2 The justification for this approach is that, in contrast to Marxian and post-Keynesian crisis theories, neo-classical and new-Keynesian economics are published in today's top-ranked economic journals. 
driving force, (ii) the rate of profits depends on long-run developments in the class struggle between workers and capitalists, and (iii) internal contradictions will periodically result in a fall of the rate of profits to a point at which capital accumulation is negatively affected. ${ }^{3}$

However, Marx's followers disagree about the main reason for the fall in the rate of profits. This is understandable as "Marx appears to associate crises with the tendency for the rate of profit to fall, with tendencies to overproduction, underconsumption, disproportionality and over-accumulation with respect to labour" (Clarke, 1994, p. 7). Furthermore, Marx is not consistent in giving primacy to any of these causes. He states, for example, in Grundrisse and in the three volumes of Capital that the law of the 'tendency of the rate of profit to fall' is fundamental to understand the limits of capitalism and that capital is the main barrier for capitalist production; however, he also writes that prior to a crisis, wages are always rising-implying that this is the main reason for the fall in profits. At the same time, Marx repeatedly stresses the point that, ultimately, crises are caused by poverty and restricted consumption. This ambiguity is not surprising, though, given that Marx never offered a full-fledged crisis theory and that most of his remarks on the vulnerability of the capitalist system to crises are not from his finished works, but they stem from notebook entries that were only published after his death (e.g. Grundrisse and Capital, Volume II and III).

Based on these different fragments on crisis theory in Marx's texts, Marxists have developed three main approaches to explain capitalist crises (Clarke, 1994; Bell \& Cleaver, 2002; Evans, 2004).

$3 \quad$ Marxists emphasize that there are several countertendencies against this fall in profit (such as increasing productivity and increasing labor resistance if wages fall); but, in their view, these tendencies work only temporarily and cannot prevent crises from occurring. The reason why lower profits lead to a crisis, and not only to a slowdown of economic growth, is the existence of the 'contract-credit system.' In a mature capitalist society, companies and financial institutions have significant credit obligations. If the profits of many capitalists drastically fall at the same time, payment obligations cannot be met in various places of the credit chain and, as a result, an economic crisis will emerge (Crotty, 1985).
Some argue that crises arise due to problems at the first stage of the accumulation process, where money is converted into constant capital (machines, raw material, etc.) and variable capital (labor). To be more precise, they argue that scarcity can lead to a 'profit squeeze' due to higher wage demands and/ or raw material costs (e.g. Glyn \& Sutcliffe, 1972; Rowthorn, 1980). A second group explains crises through the notion of an inherent contradiction in the production process. They claim that the ratio of constant to variable capital is bound to rise over time, which ultimately leads to a fall in the rate of profit (e.g. Dobb, 1937; Mattick, 1971; Shaikh, 1978). A third group argues that difficulties with selling the produced commodities at a price above production costs is the main cause of falling profit rates, i.e. problems to realize surplus value due to overproduction and/or underconsumption (e.g. Hilferding, 1910; Luxemburg, 1913; Sweezy, 1942; Baran \& Sweezy, 1966).

Initially, most of Marx's followers were stressing the importance of underconsumption to explain capitalist crises (e.g. Engels, 1975; Kautsky, 1901-02; Luxemburg, 1913). ${ }^{4}$ This theory has different strands, but the main logic behind it is that the produced surplus value needs to be realized (i.e. the output needs to be sold) to make profits and that capitalists have the tendency to produce more than what can be sold. ${ }^{5}$ This is because capitalists are producing in order to become richer (and not to fulfil people's needs and wants) and they are forced to increase their output due to competition (self-preservation), which leads to

$4 \quad$ Prior to Marx, Malthus (1820) and Sismondi (1827) developed an underconsumption theory, which, however, differs from Marx's theory in that in Malthus' and Sismondi's eyes the purpose of production is consumption and not the creation of surplus value. Their argument is in line with the view of the non-Marxist Hobson (1889 with Mummery; 1909), who argues that excessive inequality leads to excessive savings, which in turn causes a depression on the grounds that inequality limits consumption and, thus, the demand for production.

5 Another reason why the surplus value might not be realized could be that the additional output has no use-value for consumers because markets become saturated. Consequently, capitalists are always forced to invent new product lines, to open up new sectors, and to undertake huge advertising campaigns (Bell \& Cleaver, 2002; Harvey, 2010a). 
higher aggregate output. At the same time, each capitalist tries to reduce wage costs to a minimum. This strategy makes sense for every individual capitalist, but a decrease in wages leads to lower consumption demand, distorting "the relation between potential supply of and potential demand for consumption goods" and leading to "a point beyond which supply exceeds demand at normal profitable prices" (Sweezy, 1942, p. 180). ${ }^{6}$

The disproportionality theory of crisis, on the contrary, argues that the reason for overproduction problems are disproportionalities between branches of production. This crisis theory was most prominently brought forward by Hilferding (1910), who argues that increasing large-scale industrial investments by banks foster the build-up of huge amounts of fixed capital and the formation of cartels in certain branches. Lowering competition and decreasing unit costs within these branches increase their profit rates and, at the same time, lead to decreasing flows of capital to other branches of production that have lower profit rates. The outcome of this process is persistent and rising profit rate differences between branches of production and overinvestment in those branches that have relatively high profit rates. After some time, this overinvestment leads to overproduction problems and sharp falls in the rate of profit in all branches.

From the 1960s onwards, increasing numbers of Marxist scholars began to argue that neither underconsumption nor overproduction issues are the real root cause of all capitalist crises, but instead the inherent 'tendency of the rate of profit to fall. ${ }^{17}$ According to Marx, the source of the profit

$6 \quad$ Luxemburg (1913) argues that the only solution to overcome this underconsumption problem is that some part of the produced output is sold to consumers that are outside the capitalist system, thus explaining the occurrence of imperialism. However, according to this viewpoint, imperialism is only a temporary fix, given that at some point in time all spheres will be part of the capitalist system.

7 The importance of this 'law' had been stressed earlier (e.g. Dobb, 1937), but it only became the mainstream argument within Marxist circles as a result of the global recession in the 1970's (Mattick, 1971; Shaikh, 1978), given that stagflation problems during this time seemed to be based on an erosion of company profits due to an increase in the accumulation of constant capital. of capitalists is surplus value, which is created by the exploitation of variable capital. Labor output can be divided into output paid for with wages and output that is appropriated by capitalists -the bigger the latter, the higher the surplus value created by labor. The degree of exploitation, therefore, depends on real wages, labor time, and the productivity of workers. If, ceteris paribus, working time and output increase or real wages decrease, surplus value automatically increases. Having said this, Marxists also argue that, for capitalists, the main measure of success is not the surplus value, but the profitability of their investment in constant and variable capital. Consequently, supporters of the 'tendency of the rate of profit to fall' theory believe that the main reason for all crises is that capitalists have an inherent tendency to increase their constant capital stock, aiming to increase the productivity of labor and to decrease unit costs, which results in the fall of the rate of profit when the amount of constant capital increases more than the level of exploitation (i.e. the capital to surplus value ratio increases).

An important variety of this theory is the so-called regulation theory, which stresses the importance of institutions to explain the tendency of profit rates to decline (see Aglietta, 1979). The main focus of regulationists is to identify the peculiarities of institutions and social forces that give rise to 'modes of regulation' that provide temporary 'regimes of accumulations' with sustained economic growth, but that ultimately have inherent fundamental contradictions that lead to declining profit rates and mayor economic disruptions (Brenner \& Glick, 1991; Jessop, 1997; 2001; Boyer \& Saillard 2002; Setterfield, 2011; Hein et al., 2014).

Finally, the profit squeeze theory became highly popular among some Marxists in the 1970s. Their argument, in a nutshell, is that an expanding scale of operation leads to more employment in the economy, which strengthens the bargaining position of workers, as the so-called reserve-army of labor is reduced. If the subsequent rise in real wages is higher than the simultaneous increase in the exploitation of workers, capitalists' profits will fall, 
leading to less accumulation and, hence, a crisis (Glyn \& Sutcliffe, 1972; Rowthorn, 1980). ${ }^{8}$

\section{Income inequality and its role in Marxian explanations for crises}

From the above discussion it becomes clear that the issue of distribution is inherent in all Marxian crisis theories, as all these theories are based on the notion of class struggle between capitalists and workers, which, in one way or another, ultimately leads to falling profits for the former, followed by a crisis. However, the underconsumption theory is the only Marxian theory that mainly focuses on the argument that a rise in income inequality can be a root cause for capitalist crises.

Supporters of the 'tendency of the rate of profit to fall' theory argue that "neither growing worker resistance nor rising real wages are the intrinsic causes of mechanization, though they may well speed up this tendency" (Shaikh, 1978, p. 233). In their view, it is instead the pressure to expand production (as a cause of intensified competition) and to use less labor per unit produced that is the real underlying reason for the increasing investment in constant capital (Shaikh, 1978; Bell \& Cleaver, 2002; Evans, 2004). In other words, the followers of this theory see inequality as an outcome of the capitalist process, but not as the root cause of crises.

The supporters of the profit squeeze theory, on the other hand, claim that a decrease in income inequality is the root cause of crises, given that rising wages lead to higher costs and, thus, to lower profit rates.

The underconsumption theory, on the contrary, argues that a reduction in employment and in real wages substantially reduces the spending capacity of the poorer end of the population (rich

8 The profit squeeze theory has been widely criticised as being non-Marxian (see Shaikh, 1978; Clarke, 1994; Evans, 2004, for overviews of this criticism). However, this criticism is difficult to justify as Marx stressed throughout all three volumes of Capital the important role that rising wages can play in the build-up of crises (see Sweezy, 1942). capitalists also consume, but their demand for luxury goods has natural limits). Without adequate consumption demand, capitalists have no motive to increase their investment spending because their extra output cannot be sold for a profit (Sweezy, 1942; Baran \& Sweezy, 1966). Thus, according to the underconsumption theory, a significant increase in income inequality causes crises insofar that the surplus value extracted during the production process cannot be realized due to deficient demand of the working class.

In the words of Marx: "Production mediates consumption; it creates the latter's material; without it, consumption would lack an object. But consumption also mediates production, in that it alone creates for the products the subject for whom they are products. The product only obtains its 'last finish' in consumption...W Without production, no consumption; but also, without consumption, no production" (1993, p. 91). "A man who has produced does not have the choice of selling or not selling. He must sell. In the crisis there arises the very situation in which he cannot sell or can only sell below the cost price or must even sell at a positive loss" (1969, p. 508).

\section{The role of inequality in the financial crisis from a Marxian viewpoint}

Political economists that offer a 'Marxian' explanation for the financial crisis of 2007-2009 can be broadly divided into two groups. One group claims that low profit rates in the producing sector were the root cause for the crisis (e.g. Harman, 2009; Potts, 2011; Freeman, 2010; Choonara, 2009; Kliman, 2012; or, from a different perspective, Brenner, 2009). A second group argues that rising inequality and the prevention of overproduction/ underconsumption is crucial to understand why the subprime crisis occurred (e.g. Foster \& Magdoff, 2009; Kotz, 2009; Panitch \& Konings, 2009; Harvey, 2010a; Onaran, 2010a, 2010b; Lim \& Khor, 2011; Setterfield, 2010; Russo, 2012). 
Growth of financial and nonfinancial profits relative to GDP $(1970=100)$

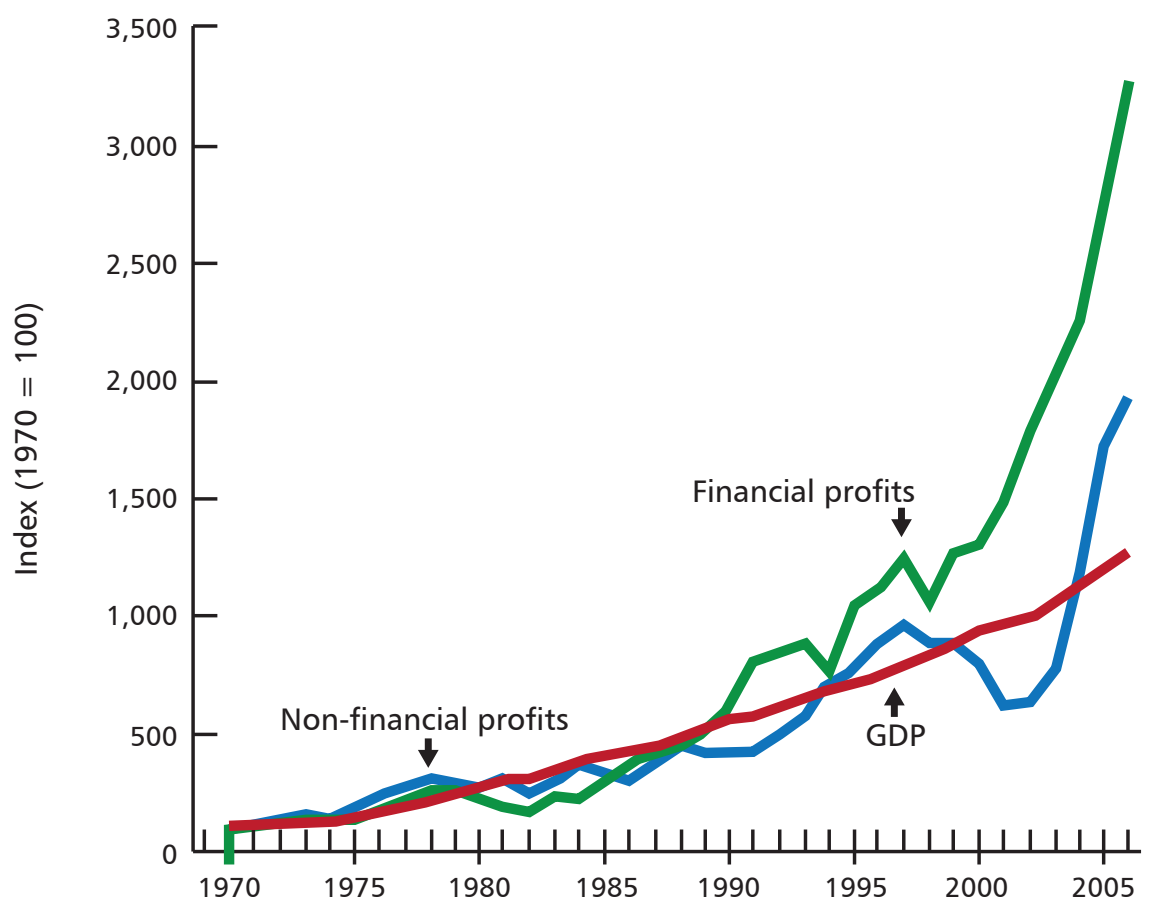

Source: Foster \& Magdoff (2008).

The latter group challenges the view of the first group regarding that low profit rates were the main underlying cause of the crisis on the grounds that the existing data suggest that from the early 1980 s onwards, corporate profit rates were recovering and growing faster than GDP (see Graph 1). ${ }^{9}$ In their point of view, institutional changes encouraged a modification in structures that contributed to rising profits and stagnant real wages, leading to increasing inequality and a potential 'capital surplus absorption problem.'

However, this potential realization problem was overcome, on the one hand, by an increase in debt levels (mainly by US and UK households) and exports (from countries like Germany, Japan, and China), and, on the other hand, by increasing

$9 \quad$ According to some Marxist scholars, the rise in profits was based mainly on rationalization, rising levels of exploitation due to stagnant/decreasing real wages and increasing productivity, as well as decreasing corporate taxes (Shaikh, 2011; Evans, 2010; Duménil \& Lévy, 2012). investment of surplus values in the financial sector. The expansion of the financial sector, the lifting of constraining regulations there, and very low interest rates meant that "[s]peculative finance became a kind of secondary engine for growth given the weakness in the primary engine, productive investment" (Foster \& Magdoff, 2009, p. 18).

As a result, consumption was stimulated by asset bubbles that led to wealth effects, while, at the same time, more funds were channeled to poor and middle-income households in the US (mainly in the form of mortgages), who, given their stagnant/ declining wages, needed those funds to sustain their status and high consumption levels. This debt-driven growth model prevented a potential underconsumption problem for some time, but ultimately was unsustainable due to its reliance on increasing household debt and on constantly rising asset prices. 


\section{POST-KEYNESIAN CRISIS THEORIES AND THE ROLE OF INCOME INEQUALITY}

\section{Post-Keynesian theories of crisis: An overview}

Post-Keynesian economics is mainly inspired by the theories of John M. Keynes, but "post-Keynesians [also] derive inspiration from a variety of [other] sources...such as Marx,...Kalecki, Kaldor, Leontief, Sraffa, Veblen, Galbraith, Andrews, GeorgescuRoegen, Hicks or Tobin, or from other disciplines (sociology, history, political science, psychology and anthropology)" (Lavoie, 2006, p. 18). Although their influences are so diverse, post-Keynesian economists are often grouped into two main strands: the fundamentalist-Keynesians (who work along the lines of Davidson, Harrod, Minsky, Kregel, Robinson, and Weintraub) and the nonfundamentalist Keynesians (who work along the lines of Eichner, Kaldor, Kalecki, Pasinetti, Robinson, Sraffa, and Steindl). This demarcation is not clear cut though-as can be seen, for example, by the inclusion of Robinson in both camps-, and the exact definition of post-Keynesianism has led to extensive debates among post-Keynesians (see, e.g., Crotty, 1980; Davidson, 2003-2004; Kerr, 2005; King, 2005; Lavoie, 2005). ${ }^{10}$

The main difference between fundamentalist and non-fundamentalist Keynesians is that the former stress the importance of the non-neutrality of money (i.e. the importance of money for real sector decisions) and fundamental (non-ergodic) uncertainty, ${ }^{11}$ while the latter concentrate their

10 Lavoie (2014, Chapter 1) shows that different authors have different views not only about the existing strands of post-Keynesians, but also about the key characteristics of post-Keynesian economics and about when post-Keynesian economics started. For simplicity reasons, and given that no clear consensus among post-Keynesians exists on these topics, in this paper the most basic distinctions are used.

11 Past information does not always permit stochastic predictions of the future according to Keynes (1937): "By 'uncertain' knowledge, let me explain, I do not mean merely to distinguish what is known for certain from what is only probable. The game of roulette is not subject, in this sense, to uncertainty...Or, again, the expectation of life is only slightly uncertain... The sense in which I am using the term research on the effects of changes in the distribution of income between workers, capitalists, and rentiers. Common denominators in post-Keynesian analyses are their emphasis on realism, uncertainty in social and institutional factors, their rejection of Say's law, their insistence on the 'fallacy of composition' (i.e. the belief that micro-foundations are often not suitable to theorize macroeconomy), and their doubt about the beneficial self-equilibration of markets. Moreover, all post-Keynesians see effective aggregate demand as the driving force of the economic system and they believe that investment determines savings, and not the other way around as neoclassical economists claim (Arestis, 1996; Lavoie, 2006, 2014). This means that postKeynesian literature discusses three main factors that can destabilize the economic system: (i) an increase in fundamental uncertainty, (ii) endogenously created financial fragility, and (iii) changes in income distribution.

According to post-Keynesians, investment is driven by expected profitability, which, in turn, is driven by (expectations about) consumption demand, labor and capital costs, prices of financial assets, and interest rates. Hence, "it is the interaction between the sum of the individual firms' sales expectations (aggregate demand) and their production costs (aggregate supply) that together determine the development in output and employment" (Jespersen, 2009, p. 199). Rising uncertainty with regard to sales expectations and production costs can therefore distort the accumulation process and lead to a crisis, i.e. it can reduce the 'animal spirits' of entrepreneurs and increase their liquidity preferences, so that they stop investing as they fear the risk involved (Ferrari-Filho \& Camargo Conceicao, 2005; Harvey, 2010b). In addition to its influence on investment and consumption, uncertainty also "necessarily gives rise to the possibility

is that in which the prospect of a European war is uncertain, or the price of copper and the rate of interest twenty years hence, or the obsolescence of a new invention, or the position of private wealth owners in the social system in 1970. About these matters there is no scientific basis on which to form any calculable probability whatsoever. We simply do not know." (pp. 213-214). 
of speculation" (Dymski, 2011, p. 331), as it can trigger a misallocation of credit, asset bubbles and bursts, over-indebtedness, and/or drastic exchange rate fluctuations (due to huge capital inflows or capital flight). The operation of the (international) financial system is hence seen as inherently unstable and crisis prone by post-Keynesian economists (Grabel, 1995; Arestis \& Glickman, 2002; Nesvetailova, 2007).

In contrast to neoclassical theory, postKeynesians believe that money is endogenously created by the system; an increase in credit demand by seemingly creditworthy agents leads to an increase in money supply by the financial system (partly through financial innovation). However, if financial actors feel that the general default risk grows, their liquidity preference increases automatically and the supply of credit will be restricted (Minsky 1986, 1992; Wray, 1990; Lavoie, 2006). A crisis can then occur if many economic units move from secure hedge financing to speculative financing, and from speculative financing to 'superspeculative' Ponzi financing. ${ }^{12}$ This is understood to occur endogenously because economic agents have the tendency to increase their level of indebtedness to (unsustainable) high levels "over periods of prolonged prosperity" (Minsky, 1992, p. 8), on the grounds that profit expectations become euphoric over time. Therefore, lending and borrowing shift endogenously from a stable to a more unstable regime, i.e. banks allow more and more firms to become hedge and Ponzi financing units that need to 'roll-over' their debt constantly. When the euphoria ends, asset prices fall and the uncertainty and liquidity preferences of financial institutions increase to the point that economic units cannot easily 'roll-over' their accumulated

12 Hedge financing implies that economic units can repay their debt and the associated interest obligations with their cash-flow. Speculative financing units are those who can pay back their interest obligations with their cash-flow but who need to 'roll-over' (part of) their debt obligations, while the cash-flow of Ponzi financing units is neither sufficient to repay their debt nor the interests resulting from this debt. Ponzi units, thus, either need to increase their debt levels or to sell assets to be able to pay their interest and debt obligations (Minsky, 1986, 1992). debt any longer (especially Ponzi financing units). Consequently, many economic units suddenly become bankrupt, triggering a financial crisis and a recession (Minsky, 1986, 1992).

Finally, changes in the wage share are also crucial for many post-Keynesians in explaining the functioning of the economic system. In their view, an increase in real wages tends to have a positive impact on the economy as it normally causes greater aggregate consumption demand (because workers have a higher propensity to consume than capitalists and rentiers). This demand leads to more employment and triggers investment by firms, which, in turn, raises productivity and makes further wage increases feasible (Palley, 2010a). Thus, a decrease of the wage share is expected to have negative consequences on aggregate consumption demand and to possibly lead to a crisis. However, an increase in the wage share can also have a negative impact on the economy; if higher wages negatively affect the cost structure of firms and thereby their (expected) profits and the (expected) volume of exports, firms will have fewer incentives to invest. This can lead to less employment and lower accumulation rates. Economies can therefore be wage-led or profit-led, depending on if the positive effect on consumption is higher or lower than the possible negative effect on investment and net exports ${ }^{13}$ (Kalecki, 1971; Rowthorn, 1981; Dutt, 1984; Bhaduri \& Marglin, 1990; Lavoie, 2006; Onaran et al., 2011; Hein, 2011).

An increase in the income share of rentiers can 'indirectly' destabilize an economy if it leads to a lower wage share and increasing debt levels of households. Furthermore, it can have 'direct' negative impacts on aggregate investment demand, because it implies an increase in shareholder value orientation, i.e. the management of firms pays

13 Empirically, "in the medium to long run, domestic demand in most of the developed capitalist economies tends to be wage-led" (Hein, 2011, p. 31). This finding is supported by a recent study, which additionally demonstrates that "a simultaneous decline in the wage share in a highly integrated global economy leads to a decline in global growth...since net export effects are fundamentally wiped out" (Onaran \& Galanis, 2014, p. 2511). 
high dividends to shareholders and buys back shares to ensure high share prices and capital gains for shareholders, instead of retaining profits. The consequence of such a financialization of the economy is that non-financial companies become increasingly leveraged and have fewer funds available to finance physical investment (Stockhammer, 2004, 2005-2006, 2008; van Treeck, 2009a). Such a finance-dominated growth regime is seen to become destabilizing if the decrease in investment spending is not offset by a sufficient increase in household consumption, and/or if it leads to an increased financial fragility due to the rising leverage ratios within the economy (Palley, 2007; van Treeck, 2009b; Hein \& van Treeck, 2010; Onaran et al. 2011; Bhaduri, 2011; Hein, 2012).

\section{Inequality and its role in post- Keynesian explanations for crises}

"Issues of class, power and distribution of income and wealth are at the heart of [post-Keynesian] analysis" (Arestis, 1996, p. 114). As outlined in the previous section, post-Keynesians argue that an increase in the profit share is likely to have a negative impact on the economy if the economy is wage-led. Similarly, an increase in the inequality of the personal income distribution can have negative consequences for the stability of the economy, because poorer segments of the population have a higher marginal propensity to consume than richer population segments, i.e. an increase in personal income inequality is expected to lead to a decrease in aggregate consumption demand (Palley, 2002; Dutt, 2012; Stockhammer, 2015b). This post-Keynesian argumentation is very similar to the Marxian underconsumption theory. In both, an increase in income inequality is seen to be a potential cause of a crisis due to a systemic consumption demand shortage, which subsequently leads to lower capital accumulation and unemployment. This similarity is to be expected, given that many of the first postKeynesians (like Kalecki, Steindl, and Robinson) and many of the modern post-Keynesians (like
Dutt, Bhaduri, Stockhammer, Hein, and Onaran, to name a few) have been strongly influenced by Marx himself and also by Marxists such as Baran and Sweezy.

The negative consequences of an increase in personal income inequality might not be immediately visible in a finance-dominated economy, though, when the poorer segments of the population are able to accumulate debt due to a greater availability of finance and because of rising asset prices (wealth-effect). Eventually, though, the rising debt, which initially ensures stable or growing aggregate consumption demand, becomes a burden to low income households as the interest obligations increase. This means that, in the long run, income is redistributed from poorer households to richer households and the consumption of poor households will be constrained. According to postKeynesians, a likely outcome of these events will be a debt-burdened recession (Palley, 1994; Bhaduri et al., 2006; Dutt, 2006).

A key post-Keynesian argument is, therefore, that ultimately "a mass-production economy needs mass-consumption markets to support it [and] robust mass-consumption markets rest on a healthy distribution of income" (Palley, 2002, p. 11), even though a demand shortage can be counteracted for some time by an increasing propensity to consume (i.e. declining private sector savings or increasing household debt levels), increased investment expenditure, increased government expenditure, and/or a trade surplus (i.e. external demand). This argument is very much in line with Keynes's original thoughts. In his General Theory of Employment, Interest, and Money, Keynes (1936, p. 372) states that one of "the outstanding faults of the economic society [is] its arbitrary and inequitable distribution of wealth and incomes." For him, they lead to a low aggregate propensity to consume, and "every weakening in the propensity to consume regarded as a permanent habit must weaken the demand for capital as well as the demand for consumption" (p. 106). 


\section{The role of inequality in the financial crisis from a post-Keynesian viewpoint}

Post-Keynesians have brought forward many different explanations. Among these explanations there have been mentioned technological and financial innovation (Pérez, 2009); imbalances in exchange rate regimes, trade, and capital flows (Wade, 2009); central bank policy failures (Morgan, 2009); and increased banking concentration and banking leverage (Tregenna, 2009). The two most widely stated reasons for crisis have been (i) failures in financial regulation in combination with Minskian instability, and (ii) the financialization of the economy, which led to an increase in inequality.

Proponents of the Minskian view claim that the subprime crisis can be regarded as 'Minskian,' because Minsky always stressed the important role of institutional changes, money managers, and securitization in the modern financial system. Moreover, the housing bubble and the growth of the subprime market represented a systemic problem that resulted from deregulation, (over) optimistic expectations and ratings, financial innovation (i.e. credit creation), the search for high returns, rising asset prices, high leverage, and Ponzi finance schemes. All of these took place in a prolonged period of relative stability-the so caIled Great Moderation period (Kregel, 2007; Wray, 2008, 2009; Vercelli, 2011; Sau, 2013).

Economists who discuss the subprime crisis in the light of Minskian instability only mention inequality in passing, if at all. Two notable exceptions are Dymski (2010) and Kaboub et al. (2010). Kaboub et al. argue that "a major contributing factor to the conditions leading to aggressive subprime lending behavior is the build-up and persistence of economic inequality that has intensified since 1980" (p. 9), while Dymski stresses that an important institutional feature of the subprime crisis was that banks increasingly targeted low income minorities who had previously been excluded from financial markets. However, both authors concentrate more on other issues than on inequality.
The advocates of the financialization theory, on the contrary, claim that income inequality needs to be at the heart of the analysis. They argue that the crisis began to build up when "[s]lower growth, higher inflation and unemployment, and falling profits and stock prices created growing discontent with the economic status quo" at the end of the 1970s (Crotty, 2012, p. 83). This led to economic coalitions, which radically deregulated financial markets, while, at the same time, institutional investors gained importance and the market for corporate control developed. The outcome of these developments was the enormous growth of the financial sector and an increase in functional and personal income inequality (Stockhammer, 2008; Palma, 2009; Evans, 2010; Crotty, 2012).

The overall outcome should have been a lack of aggregate demand. This was, however, circumvented by a decrease in saving rates and an increase of debt-financed consumption in some countries (the UK and US), and by an increasing reliance on exports in 'mercantilist' countries (China, Germany, and Japan). This post-1980 global debt- and export-led growth regime relied, above all, on the increase in consumption expenditure and private housing investment in the US (see Figure 1). Apparently, US households lived for very long beyond their means in an effort to keep their social status relative to the wealthier members of society. This behavior gave rise to an 'expenditure cascade' in which middle-income and poor households were only able to keep up with the rapidly increasing consumption of the top income earners by curtailing their savings and increasing their borrowing (Barba \& Pivetti, 2009; Palley, 2010a, 2010b; Stockhammer 2015b; Hein \& Truger, 2012-2013; van Treeck 2014).

This increase in personal debt levels was unsustainable in the long run and led to a 'quasi' Minskian instability in the household sector. Households engaged in Ponzi finance to fund consumption relied on increasing house prices to be able to pay back their increasing debt. When the Fed increased the interest rates and the housing bubble burst, these over-indebted subprime 


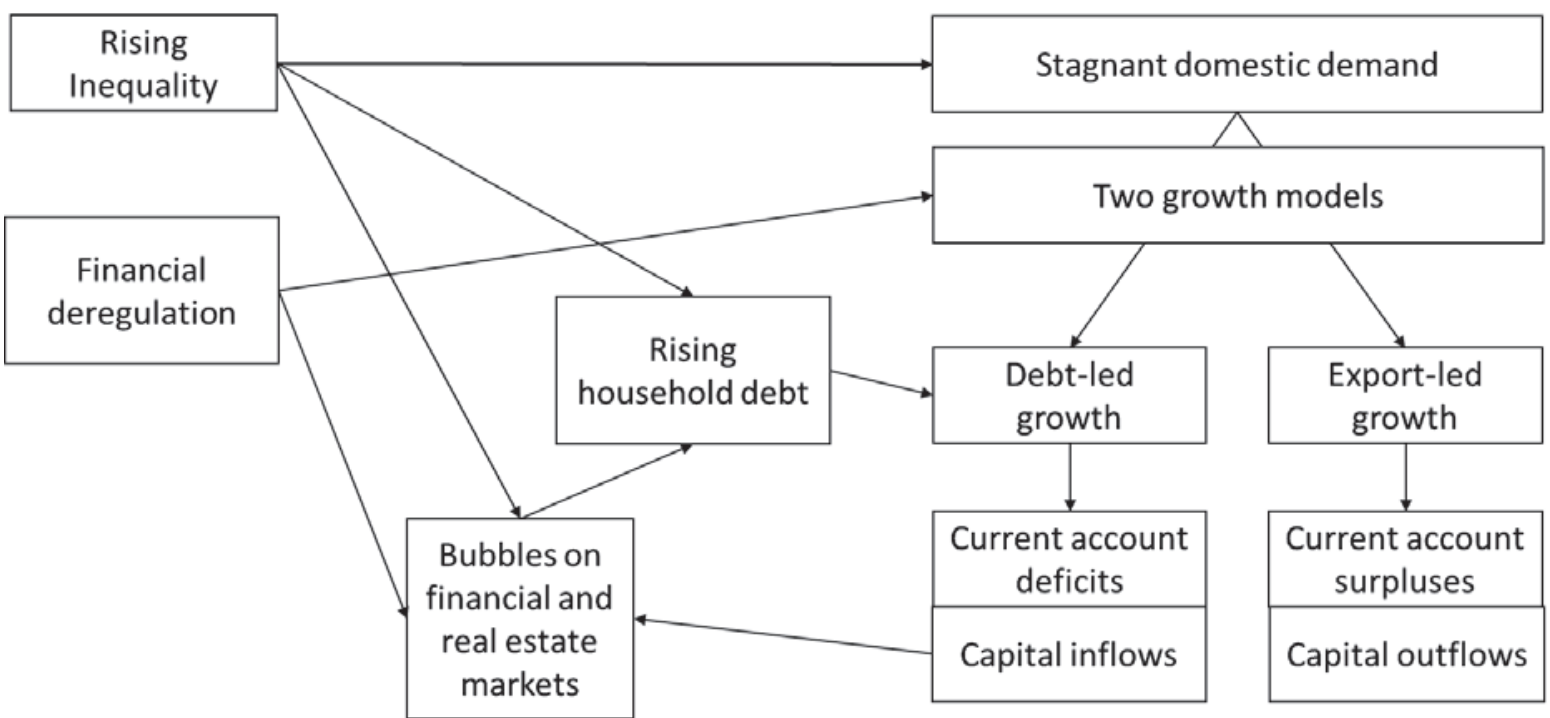

Source: Stockhammer (2015b)

borrowers naturally could no longer repay their debt. This led to mass foreclosures and the breakdown of the market for collateralized debt obligations (Palley, 2010b; Setterfield, 2010).

\section{MAINSTREAM CRISIS THEORIES AND THE ROLE OF INCOME INEQUALITY}

\section{Mainstream theories of crisis: An overview}

In contrast to post-Keynesians and Marxists, orthodox mainstream economists maintain that free market operations will ensure that the system is self-regulating via an 'invisible hand' and that economies have equilibrium tendencies, i.e. crises are only exceptional deviations from the normal growth path. To be more precise, neo-classical economists believe that the system is self-regulated via the forces of supply and demand. Therefore, they claim that markets, interest rates, and exchange rates need to be fully flexible. This general equilibrium theory is based on the economic theory of classical economists like Smith, ${ }^{14}$ Mill, and Ricardo and assumes that full-employment is the norm; that rational economic agents are maximizing utility and are fully-informed and homogenous in their behavior; that no fundamental uncertainty exists; that money is neutral; and that markets are perfectly efficient. The resulting efficient market theory implies that assets cannot be persistently over- or undervalued, as investors would take advantage of price differences. Hence, prices will return nearly immediately to their 'fundamental values' via arbitrage (Friedman, 1953; Fama, 1970, 1991; Nesvetailova, 2007). According to this neoclassical view, rationality will ensure that banks only grant credit to creditworthy borrowers and that borrowers will only demand credits up to a level to which they are able to repay the loan with

14 Although Smith "himself took a broader perspective on self-interest than his modern-day disciples [and] used the term 'invisible hand' with some irony" (Stiglitz, 2011, p. 591). 
their (rightly expected) future income streams. Additionally, it is assumed that a prudent monetary policy (i.e. a tight money supply) will ensure low and stable inflation rates. Consequently, crises are seen not as systemic failures of the real or financial sector, but as the result of external shocks to the system (like overly high government debt levels that lead to 'debt intolerance' by investors, as prominently argued by Reinhart \& Rogoff, 2010).

To be more precise, the system is always thrown out of equilibrium due to random exogenous factors, even if this crisis seemingly happened endogenously. In Diamond and Dybvig's (1983) model, for example, a bank run occurs 'endogenously,' because lenders know that banks are not able to repay all the deposits at the same time due to the intrinsic maturity mismatch between deposits and credits. The initial reason why depositors want to have their money back is, nonetheless, related to external shocks such as an unpredictable need for cash or a collapse in asset prices (Allen \& Gale, 2007). On these grounds, crises are regarded as market self-corrections, which are necessary to overcome sporadic exogenous disturbance and/or misguided government policies, as well as to ensure the long-term healthiness of the system.

Research on financial crises in emerging economies by mainstream economists has put some doubt on this orthodox notion that markets work perfectly fine when they are left on their own. The new-Keynesian Krugman (1979), in his so-called first-generation model on financial crises, was one of the first mainstream economists who claimed that fundamental macroeconomic variables can be negatively influenced by imbalances in the balance of payments of countries. This strand of research was further developed in the so-called second-, third-, and fourth-generation models of financial crises after they became a widespread problem in developing economies in the 1990s (Muñoz, 2011). The latter models claim that in financially open economies negative effects of massive capital outflows, together with changes in the creditworthiness of the balance sheets of the economy are the two key components to explain financial crises.
To be more precise, the chain of reaction leading to a financial crisis is seen as follows: (i) countries receive external capital and become indebted in foreign currency; (ii) at some point, investors' perception of the riskiness of the domestic balance sheets changes, which leads to massive capital outflows (e.g. due to expected depreciation or contagion); (iii) this capital flight weakens the currency and exhausts the reserves of a country; (iv) the already weakened local currency collapses; (v) highly leveraged entities within the country are unable to repay their external (short-term) debts; and (vi) a financial crisis breaks out, leading to a recession (see, e.g., Krugman, 1999; Dornbusch, 2001; Tornell et al., 2004).

The general assumption about the stability and efficiency of markets was most prominently challenged by the new-Keynesian Nobel Prize winners Akerlof (1970) and Stiglitz (with Rothschild, 1976) and their theory of imperfect and asymmetric information. According to this theory, not all market participants have the same information and, therefore, markets do not work as perfectly as orthodox economists claim. First, there are difficulties retrieving the costs necessary to receive 'first-hand' information, because this information spreads quickly in the market. Second, one party might have better information than other parties (e.g. a borrower is better informed about the riskiness of an investment than the lender). In other words, market incentives exist (i) to minimize the costs in acquiring information, (ii) to conceal information to other market participants (e.g. agency problems), and (iii) to insure against risk (e.g. credit rationing). This means that market disequilibria can arise endogenously (see Stiglitz (2002) and Rosser (2003) for more details).

Accordingly, an economic crisis can result from an economic downturn, which "may be initiated by an oil price shock, a monetary shock, or a dramatic change in expectations" (Stiglitz, 1992, p. 284). After this shock, information imperfections in the equity market can lead to the situation that "relatively small fractions of new capital is raised by new equity issues" (p. 278). In addition, 
banks are starting to restrict their lending, whereas during the pre-downturn period most investment is financed with credits. The consequence of this is not only that firms will invest less and hire fewer workers-which has negative impacts on aggregate demand-, but also that many firms will go bankrupt due to their high debt levels. This, in turn, will lead to further lending restrictions and less equity issues, as well as to a further exacerbation of the crisis. This theory is directly linked to the third- and fourth-generation models of financial crises, because imperfect and asymmetric information is seen to be crucial to understanding why "a sudden change in lenders' perceptions concerning 'emerging market risk' can lead to huge capital outflows, undermining the viability of the entire financial system" (Stiglitz, 2000, p. 1080).

However, in all these mainstream models of financial fragility it is argued that a crisis does not develop endogenously, but it necessarily "... is a situation in which small shocks have a significant impact on the financial system" (Allen \& Gale, 2007, p. 126). These external shocks may be trivial (bankruptcy, refusal of credit, suicide, etc.), but they are significant enough to change the perceptions of market participants or compromise an important actor in the system.

Another mainstream strand that challenges the position of the endogenous stability of markets, which has gained more and more attention in recent years, is the so-called behavioral finance theory. This theory is based on Kahneman and Tversky's (1979) work and related to Kindleberger's (1978) mania and panic theory, and was most prominently put forward by authors like Shiller (2000), Shleifer (2000), and Akerlof (2002; 2009 with Shiller). These authors argue that psychological factors like greed, loss of self-control, investor's preferences, overconfidence and optimism, as well as under- and over-reactions due to herding behavior explain financial instability. In other words, the theory assumes that 'non-rational' behavior leads to speculation and to the deviation of market prices from their 'fundamental' value and explains why bubbles and financial crashes occur recurrently.
However, today's most widely used mainstream models, the Dynamic Stochastic General Equilibrium (DSGE) models, normally (i) do not consider the findings of behavioral finance (i.e. they rely on the assumption that all individuals are identical, utility-maximizing, and rational); (ii) they treat incomplete and asymmetric information and agency problems only as special cases; (iii) they do not incorporate money, the financial sector (e.g. no borrowing and lending takes place), and/or the government sector in a meaningfully realistic sense; and (iv) they do not take into account that macroeconomic outcomes can be very different from the existing micro-foundations. Due to these shortcomings and, more importantly, because these 'New Consensus' models "have failed [to] predict that the financial crisis would happen; and [to] understated its effects" (Stiglitz, 2011, p. 591), their usefulness is increasingly questioned (see Stiglitz, 2011 for a detailed discussion of the limitations of DSGE models).

\section{Inequality and its role in mainstream explanations of crises}

From the previous discussion it becomes clear that income inequality does not play a prominent role in mainstream discussions of crises. Strangely, this is also true for behavioral economics, which does not discuss changes in the behavior of households based on changes in inequality levels. To be more precise, mainstream economists normally see inequality as a legitimate outcome of differences in skills and productivity, which is not expected to have a destabilizing effect on the economic system. This is because changes in earnings, debt, and savings are seen as optimal in an economic sense, Say's law is assumed to hold (i.e. supply creates its own demand), and full-employment is assumed as the norm. On the basis of these assumptions, libertarians like Hayek (1982) argue that the redistribution of income is 'unjust' because it does not only deprive individuals of their freedom, but also reduces overall welfare due to a loss of economic efficiency. 
The fact that inequality is not prominent in mainstream research can also be seen from the fact that the vast majority of DSGE models are based on one representative agent (a notable exception is the work by Kumhof et al. (2015), which is discussed below). This means that "there are no distributive issues [and] no scope for exploitation [because] what the worker loses through lower wages, he/ she gets back in his/her role as 'owner' through higher profits" (Stiglitz, 2011, p. 598). Furthermore, DSGE models normally disregard the possibility of excess indebtedness, as no financial market is included in most models. Hence, according to the vast majority of mainstream theories and models, rising inequality will have neither a negative impact on aggregate demand nor will it lead to financial instability.

Even if capital markets are taken into accou$n t$, mainstream theories of consumption "... see no link between the inequality of (permanent) income and aggregate personal consumption, and hence no need for government action..." (van Treeck \& Sturn, 2012, p. 1). The reason for this view is that households are expected to be able to smooth fluctuations in income with the help of financial markets. Inequality is, therefore, normally seen to be influenced by transitory changes (e.g. depending on the age of the individual) and not by permanent changes in lifetime income (Krueger \& Perri, 2006).

\section{The role of inequality in the financial crisis from a mainstream viewpoint}

The majority of mainstream economists think that either "there is no convincing link that would enable us to associate high levels of income inequality with the financial crisis" (Roháč, 2011, p. 1) or that inequality might have played a facilitating role but other factors were much more important. The most often discussed root causes of the crisis are, therefore, the lack of regulation (see, e.g., Acharya \& Richardson, 2009; Davies, 2010), greed on the part of the banks (see, e.g., Brummer, 2009), the widespread undervaluation of risk (see, e.g., IMF,
2008; Stiglitz, 2009; White, 2009), and global imbalances together with misguided economic policies (see, e.g., Obstfeld \& Rogoff, 2009; Taylor, 2009).

Nevertheless, well-known mainstream economists are increasingly acknowledging that income inequality was an important contributing factor to the crisis (e.g. Rajan, 2010; Roubini, 2011). Among them, Stiglitz $(2009,2012)$ has made the strongest case for a role of inequality in the crisis. His argument is very similar to those of heterodox economists. Stiglitz argues that aggregate demand in both the US, specifically, and in the world, in general, would have been insufficient without the lax monetary policy after 2001, the stock market bubble, and then the housing bubble that "fuelled a consumption boom that allowed Americans to live beyond their means" (2012, p. 54) to keep up with the living standards of the richer parts of the population. This behavior was unsustainable in the long run as households became overleveraged and the housing bubble could not last forever. For Stiglitz, the main reasons for this problem are asymmetric information and rent seeking that led to market distortions, along with coordination and macroeconomic failures.

Kumhof et al. (2012) are conceptualizing the argument that rising inequality led to imbalances and rising household debt by using an open economy DSGE model based on a closed economy DSGE model developed by Kumhof and Rancière (2010) and extended by Kumhof et al. (2015). Both models have two groups of households: investors (the top $5 \%$ of the population) and workers (the bottom $95 \%$ of households). In the closed economy model, crises result from an external 'bargaining power shock' that results in increasing inequality. The increase in inequality leads to higher credit demand from workers (see Graph 2), who seek to smooth consumption, while the top $5 \%$ recycle their gains to poorer households in the form of loans.

Over time, workers become over-indebted and "large-scale household debt defaults [leading to] an abrupt output contraction" (Kumhof \& 
Panel A. Great Recession: debt-to-income ratios

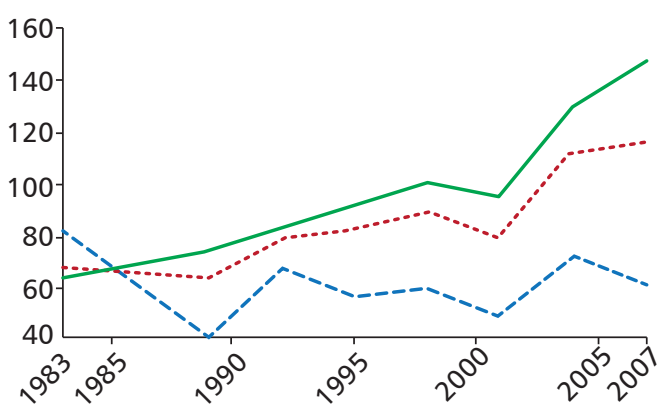

$$
\begin{aligned}
& \text { Bottom } 95 \text { percent of the income distribution } \\
& \text {......... Aggregate economy }
\end{aligned}
$$

Source: Kumhof et al. (2015b)

Rancière, p. 1). The 2012 extension of the model simulates a two-country case, where the rich population in a country with a less developed financial market (China) finances the debt of the poor population in a country with a highly developed financial market (US). Over time, this situation results in increasing current account deficits and the over-indebtedness of workers in the rich country, and capital outflows and current account surpluses in the poor country. The authors conclude that this model depicts the developments that were observed prior to the financial crisis.

\section{CONCLUSIONS}

The review has shown that the issue of distribution is inherent in all Marxian crisis theories, as they are all based on the notion of class struggle between capitalists and workers. However, the only Marxian theory that sees rising income inequality as the root cause for crises is the overproduction/underconsumption theory. For many post-Keynesians, possible aggregate demand problems due to changes in the income distribution between workers, capitalists, and rentiers are also at the heart
Panel B. Great Recession:

new loans relative to income

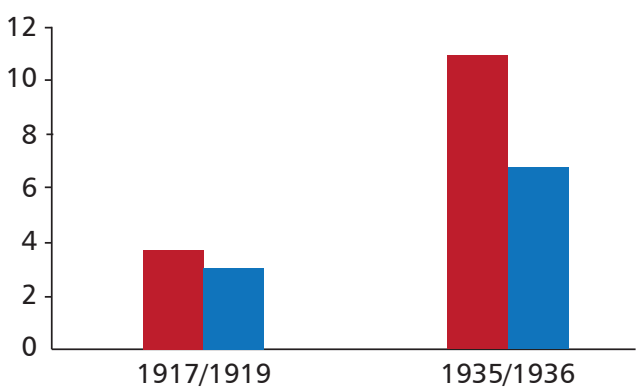

- Bottom 95 percent of the income distribution Top 5 percent of the income distribution

of the analysis, but fundamental uncertainty and Minskian instability (which are not normally related to inequality by post-Keynesians) are at least as prominent in their crisis theories. Mainstream theories and models, in contrast, did not regard inequality as a destabilizing factor prior to the crisis (with very few exceptions).

One important difference between the three strands is their view about the role of government. Most mainstream economists see crises as healthy deviations from the normal growth path of a selfregulating system in which the government should intervene as little as possible. Many Marxists believe that a capitalist economy is necessarily driven by 'growth-crisis cycles' a la Goodwin (1967) and that government intervention cannot prevent crises in the long run. Post-Keynesians often argue that crises can be avoided if countercyclical fiscal and monetary policies are implemented, financial markets are sufficiently regulated, and the 'golden rule' is followed that real wage growth is in line with labor productivity growth (Palley, 2010a; Hein \& Stockhammer, 2011).

In spite of their different theoretical frameworks, economists of all three strands offer a 
similar explanation on why income inequality was an important contributing factor to the financial crisis of 2007-2009: a possible global aggregate consumption demand shortage was circumvented by a massive increase in household borrowing in some countries and a mercantilist export-led growth strategy in other countries. Over time, the global balance of payments imbalances increased and especially many of the bottom $90 \%$ of US households became over-indebted. The collapse of this system occurred in August 2007 when the delinquency rates of US households on subprime mortgages became too high. The subsequent breakdown of the CDO market made the bailouts of banks across the world necessary and culminated in a global credit crunch and recession. This analysis indicates that high levels of economic inequality not only can have adverse social impacts, but also can foster economic instability.

\section{REFERENCES}

1. Acharya, V., \& Richardson, M. (2009). Restoring Financial Stability: How to Repair a Failed System. Hoboken: Wiley.

2. Aglietta, M. (1979). A Theory of Capitalist Regulation. London: New Left Books.

3. Akerlof, G. A. (1970). The market for lemons: quality uncertainty and the market mechanism. Quarterly Journal of Economics, 84(3): 488-500.

4. Akerlof, G. A. (2002). Behavioral macroeconomics and macroeconomic behaviour. American Economic Review, 92(3): 411-433.

5. Akerlof, G. A., \& Shiller, R. J. (2009). Animal Spirits: How human psychology drives the economy, and why it matters for global capitalism. Princeton: Princeton University Press.

6. Allen, F., \& Gale, D. (2007). Understanding Financial Crises. New York: Oxford University Press.

7. Arestis, P. (1996). Post-Keynesian economics: towards coherence. Cambridge Journal of Economics, 20(1): $111-135$

8. Arestis, P., \& Glickman, M. (2002). Financial crisis in Southeast-Asia: dispelling illusion the Minskyan way. Cambridge Journal of Economics, 26(2): 237-260.

9. Ashcraft, A. B., \& Schuermann, T. (2008). Understanding the securitization of subprime mortgage credit. FR Bank Staff Report, No. 318. New York: Federal Reserve Bank of New York. Retrieved from: https://www. newyorkfed.org/medialibrary/media/research/staff_reports/sr318.pdf.

10. Atkinson, A. B. (1997). Bringing income distribution in from the cold. The Economic Journal, 107(441): $297-321$

11. Baran, P., \& Sweezy, P. M. (1966). Monopoly Capital. New York: Monthly Review Press.

12. Barba, A., \& Pivetti, M. (2009). Rising household debt: Its causes and macroeconomic implications-a long-period analysis. Cambridge Journal of Economics, 33(1): 113-137.

13. Bell, P., \& Cleaver, H. (2002). Marx's theory of crisis as a theory of class struggle. The Commoner, 5: 1-61 (first published in Research in Political Economy, 5 (1982)).

14. Bhaduri, A. (2011). A contribution to the theory of financial fragility and crisis. Cambridge Journal of Economics, 35(6): 995-1014.

15. Bhaduri, A., \& Marglin, S. (1990). Unemployment and the real wage: the economic basis for contesting political ideologies. Cambridge Journal of Economics, 14(4): 375-393. 
16. Bhaduri, A., Laski, K., \& Riese, M. (2006). A model of interaction between the virtual and the real economy. Metroeconomica, 57(3): 412-427.

17. Boyer, R. (2000). Is a finance-led growth regime a viable alternative to Fordism? A preliminary analysis'. Economy and Society, 29(1): 111-145.

18. Boyer, R. (2012). The Present Crisis. A Trump for a Renewed Political Economy. Review of Political Economy, 25(1): 1-38.

19. Boyer, R., \& Saillard, Y. (2002). Régulation Theory. The State of the Art. London/New York: Routledge.

20. Brenner, R. (2009). What is good for Goldman Sachs is good for America; the origins of the current crisis. Retrieved from http://www.sscnet.ucla.edu/issr/cstch/papers/BrennerCrisisTodayOctober2009.pdf.

21. Brenner, R., \& Glick, M. (1991). The regulation approach: theory and history. New Left Review, 188: 45-119.

22. Brummer, A. (2009). The Crunch: How Greed and Incompetence Sparked the Credit Crisis. London: Random House Business Books.

23. Choonara, J. (2009, June 24). Marxist accounts of the current crisis. International Socialism, 123. Retrieved from http://isj.org.uk/marxist-accounts-of-the-current-crisis/.

24. Clarke, S. (1994). Marx's Theory of Crisis. Basingstoke: Macmillan Press.

25. Crotty, J. R. (1980). Post-Keynesian Economic Theory: An Overview and Evaluation. American Economic Review, $70(2):$ 20-25.

26. Crotty, J. R. (1985). The Centrality of Money, Credit and Financial Intermediation in Marx's Crisis Theory. In S. Resnick \& R. Wolff (Eds.), Rethinking Marxism: Essays in Honor of Harry Magdoff and Paul Sweezy (pp. 45-82). New York: Autonomedia.

27. Crotty, J. R. (2012). The great austerity war: what caused the US deficit crisis and who should pay to fix it? Cambridge Journal of Economics, 36(1): 79-104.

28. Davidson, P. (2003-2004). Setting the record straight on "A history of Post Keynesian economics." Journal of Post Keynesian Economics, 26(2): 245-272.

29. Davies, H. (2010). Global Financial Regulation after the Credit Crisis. Global Policy, 1(2): 185-190.

30. Diamond, D. W., \& Dybvig, P. H. (1983). Bank Runs, Deposit Insurance, and Liquidity. Journal of Political Economy, 91(3): 401-419.

31. Dobb, M. (1937). Political economy and capitalism. London: Routledge.

32. Dornbusch, R. (2001). A primer on emerging market crisis. NBER Working Paper No. 8326.

33. Duménil, G., \& Lévy, D. (2012). The Crisis of the Early 21st Century: Marxian perspectives. In R. Bellofiore \& G. Vertova (Eds.), The Great Recession and the contradictions of contemporary capitalism (pp. 26-49). Aldershot: Edward Elgar.

34. Dutt, A. K. (1984). Stagnation, income distribution and monopoly power. Cambridge Journal of Economics, $8(1): 25-40$.

35. Dutt, A. K. (2006). Maturity, stagnation and consumer debt: a Steindlian approach. Metroeconomica, 57(3): 339-364.

36. Dutt, A. K. (2012). Growth, distribution and crises. In H. Herr, T. Niechoj, C. Thomasberger, A. Truger $\&$ T. van Treeck (Eds.), From crisis to growth? The challenge of debt and imbalances (pp. 33-59). Marburg: Metropolis Verlag. 
37. Dymski, G. (2010). Why the subprime crisis is different: A Minskyian approach. Cambridge Journal of Economics, 34(2): 239-255.

38. Dymski, G. (2011). Keynesian Approaches to financial crisis. In E. Hein \& E. Stockhammer (Eds.), A modern guide to Keynesian macroeconomic and economic policies (pp. 325-352). Cheltenham: Edward Elgar Publishing.

39. Engels, F. (1975). Anti-Dühring: Herr Eugen Dühring's Revolution in Science. London: Lawrence \& Wishart.

40. Evans, T. (2004). Marxian and post-Keynesian theories of finance and the business cycle. Capital EB Class, 28(2): 47-100.

41. Evans, T. (2010). Five explanations for the international financial crisis. IPE Working Paper No. 08/2010.

42. Fama, E. F. (1970). Efficient Capital Markets: a review and empirical work. Journal of Finance, 25(2): $383-417$.

43. Fama, E. F. (1991). Efficient Capital Markets: II. Journal of Finance, 46(5): 1575-1617.

44. Ferrari-Filho, F., \& Camargo Conceicao, O. A. (2005). The concept of uncertainty in Post Keynesian theory and in institutional economics. Journal of Economic Issues, 39(3): 579-594.

45. Foster, J. B., \& Magdoff, F. (2008). Financial Implosion and Stagnation. Monthly Review, 60(7). Retrieved from http://monthlyreview.org/2008/12/01/financial-implosion-and-stagnation/.

46. Foster, J. B., \& Magdoff, F. (2009). The great financial crisis: causes and consequences. New York: Monthly Review Press.

47. Freeman, A. (2010). Marxism without Marx: a note towards a critique. Capital and Class, 34(1): 84-97.

48. Friedman, M. (1953). Essays in Positive Economics. Chicago: University of Chicago Press.

49. Glyn, A., \& Sutcliffe, B. (1972). British capitalism, workers and the profit squeeze. Harmondsworth: Penguin.

50. Goda, T. (2016). Global trends in relative and absolute income inequality. Ecos de Economía: A Latin American Journal of Applied Economics, 20(42): 46-69.

51. Goodwin, R. M. (1967). A Growth Cycle. In C. H. Feinstein (Ed.), Socialism, Capitalism and Economic Growth (pp. 54-58). Cambridge: Cambridge University Press.

52. Grabel, I. (1995). Speculation-led economic development: a post-Keynesian interpretation of financial liberalization programmes in the Third World. International Review of Applied Economics, 9(2): 127-149.

53. Harman, Ch. (2009). Zombie Capitalism: Global crisis and the relevance of Marx. London: Bookmarks Publications.

54. Harvey, D. (2010a). The enigma of capital: and the crises of capitalism. London: Profile Books.

55. Harvey, J. T. (2010b). Modelling financial crisis: a schematic approach. Journal of Post Keynesian Economics, $33(1): 61-82$.

56. Hayek, F. A. (1982). Law, Legislation and Liberty: A new statement of the liberal principle of justice and political economy. London: Routledge \& Kegan Paul.

57. Hein, E. (2011). Distribution, 'Financialisation' and the Financial and Economic Crisis Implications for Postcrisis Economic Policies. MPRA Working Paper No. 31180.

58. Hein, E. (2012). Finance-dominated capitalism, re-distribution, household debt and financial fragility in a Kaleckian distribution and growth model. PSL Quarterly Review, 65 (260): 11-51. 
59. Hein, E., \& Stockhammer, E. (2011). A post-Keynesian macroeconomic model of inflation, distribution and employment. In E. Hein \& E. Stockhammer (Eds.), A modern guide to Keynesian macroeconomic and economic policies (pp. 112-136). Cheltenham: Edward Elgar.

60. Hein, E., \& Truger, A. (2012-2013). Finance-dominated capitalism in crisis - the case for a global Keynesian New Deal. Journal of Post Keynesian Economics, 35(2): 187-214.

61. Hein, E., \& van Treeck, T. (2010). 'Financialisation' in Post-Keynesian models of distribution and growth-a systematic review. In M. Setterfield (Ed.), Handbook of Alternative Theories of Economic Growth (pp. 277 292). Cheltenham: Edward Elger.

62. Hein, E., Dodig, N., \& Budyldina, N. (2014). Financial, economic and social systems: French Regulation School, Social Structures of Accumulation and Post-Keynesian approaches compared. IIPE Working Paper No. 34/2014.

63. Hilferding, R. (1910). Das Finanzkapital. Eine Studie über die jüngste Entwicklung des Kapitalismus. Vienna: Wiener Volksbuchhandlung.

64. Hobson, J. A. (1909). The Industrial System: An inquiry into earned and unearned income. London: Longmans, Green and Co.

65. IMF. (2008). Global Financial Stability Report: Containing Systemic Risks and Restoring Financial Soundness. Washington D.C.: International Monetary Fund.

66. Jespersen, J. (2009). Macroeconomic Methodology: A Post-Keynesian Perspective. Cheltenham: Edward Elgar Publishing.

67. Jessop, B. (1997). Capitalism and its future: remarks on regulation, government, and governance. Review of International Political Economy, 4(3): 435-455.

68. Jessop, B. (2001). Regulation Theory and the Crisis of Capitalism. Cheltenham: Edward Elgar.

69. Kahneman, D., \& Tversky, A. (1979). Prospect theory: An Analysis of Decision Under Risk. Econometrica, $47(2): 263-91$.

70. Kaboub, F., Todorova, Z., \& Fernández, L. (2010). Inequality-led financial instability: A Minskian structural analysis of the subprime crisis. International Journal of Political Economy, 39(1): 3-27.

71. Kalecki, M. (1971). Selected Essays on the Dynamics of the Capitalist Economy. Cambridge University Press: Cambridge.

72. Kautsky, K. (1901-02). Krisentheorien. Die Neue Zeit, 20(2): 37-143.

73. Kenway, P. (1980). Marx, Keynes and the possibility of crisis. Cambridge Journal of Economics, 4(1): 23-36.

74. Kerr, P. (2005). Review Article: A history of post-Keynesian economics. Cambridge Journal of Economics, 29(3): 457-496.

75. Keynes, J. M. (1936). The General Theory of Employment, Interest and Money. London: Macmillan (1960 reprint).

76. Keynes, J. M. (1937). The general theory of employment. Quarterly Journal of Economics, 51 (2): $209-223$.

77. Kindleberger, C. P. (1978). Manias, Panics and Crashes. New York: Basic Books.

78. King, J. E. (2002). A History of Post Keynesian Economics Since 1936. Cheltenham: Edward Elgar.

79. King, J. E. (2005). Unwarping the record: a reply to Paul Davidson. Journal of Post Keynesian Economics, 27(3): 377-384. 
80. Kliman, A. (2012). The Failure of Capitalist Production: Underlying Causes of the Great Recession. London: Pluto Press.

81. Kotz, D. M. (2009). The Financial and Economic Crisis of 2008: A Systemic Crisis of Neoliberal Capitalism. Review of Radical Political Economics, 41 (3): 305-317.

82. Kregel, J. (2007). The Natural Instability of Financial Markets. Working Paper No. 523. Annandale-onHudson, NY: Levy Economics Institute. Retrieved from: http:/www.levyinstitute.org/pubs/wp_523.pdf

83. Krueger, D., \& Perri, F. (2006). Does income inequality lead to consumption inequality? Evidence and theory. Review of Economic Studies, 73(1): 163-193.

84. Krugman, P. (1979). A model of balance-of-payments crises. Journal of Money, Credit, and Banking, 11 (3): 311-325.

85. Krugman, P. (1999). Balance sheets, the transfer problem, and financial crises. International Tax and Public Finance, 6(4): 459-472.

86. Kumhof, M., \& Rancière, R. (2010). Inequality, leverage and crises. IMF Working Paper No. 268.

87. Kumhof, M., Lebarz, C., Rancière, R., Richter, A. W., \& Throckmorton, N. A. (2012). Income Inequality and Current Account Imbalances. IMF Working Paper No. 12/08.

88. Kumhof, M., Ranciére, R., \& Winant, P. (2015). Inequality, Leverage, and Crises. American Economic Review, 105(3):1217-1245.

89. Lavoie, M. (2005). Changing definitions: a comment on Davidson's critique of King's history of Post Keynesianism. Journal of Post Keynesian Economics, 27(3): 371-376.

90. Lavoie, M. (2006). Introduction to Post-Keynesian Economics. Houndmills: Palgrave Macmillan.

91. Lavoie, M. (2014). Post-Keynesian Economics: New Foundations. Cheltenham: Edward Elgar.

92. Lim, M.-H., \& Khor H. E. (2011). From Marx to Morgan Stanley: Inequality and Financial Crisis. Development and Change, 42(1): 209-227.

93. Luxemburg, R. (1913). The accumulation of capital. London: Butler \& Tanner.

94. Major, A. (2012). Neoliberalism and the new international financial architecture. Review of International Political Economy, 19(4), 536-61.

95. Malthus, T. R. (1820). Principles of political economy considered with a view to their practical application. London: John Murray.

96. Marx, K. (1969). Theories of Surplus Value, part 2. London, Lawrence and Wishart.

97. Marx, K. (1993). Grundrisse: Foundations of the Critique of Political Economy (Rough Draft). Penguin Books: London.

98. Mattick, P. (1971). Marx and Keynes: the limits of the mixed economy. London: Merlin Press.

99. Minsky, H. P. (1986). Stabilizing an Unstable Economy. New Haven: Yale University Press.

100. Minsky, H. P. (1992). The Financial Instability Hypothesis. Levy Economics Institute Working Paper No. 74.

101. Morgan, J. (2009). The limits of central bank policy: economic crisis and the challenge of effective solutions. Cambridge Journal of Economics, 33(4): 581-608.

102. Mummery, A. F., \& Hobson, J. A. (1889). The Physiology of Industry: Being an exposure of certain fallacies in existing theories of economics. London: John Murray. 
103. Muñoz, J. (2011). Orthodox versus Heterodox (Minskyan) Perspectives of Financial Crises: Explosion in the 1990s versus Implosion in the 2000s. Levy Economics Institute Working Paper No. 659.

104. Nesvetailova, A. (2007). Fragile Finance: Debt, Speculation and Crisis in the Age of Global Credit. Basingstoke: Palgrave Macmillan

105. Obstfeld, M., \& Rogoff, K. S. (2009). Global Imbalances and the Financial Crisis: Products of Common Causes. Asia and the Global Financial Crisis. Asia Economic Policy Conference, Santa Barbara, CA, October 18-20, 2009, Federal Reserve Bank of San Francisco. Retrieved from: http://scholar.harvard.edu/files/ rogoff/files/global_imbalances_and_financial_crisis_0.pdf.

106. Onaran, Ö. (2010a). Global crisis and the policy reaction in Western and Eastern European Union: can policy save capitalism from itself? International Viewpoint. Retrieved from http://internationalviewpoint.org.

107. Onaran, Ö. (2010b): The Crisis of Capitalism in Europe, West and East. Monthly Review, 62 (5): online.

108. Onaran, Ö., \& Galanis, G. (2014). Income distribution and growth: a global model. Environment and Planning A, 46(10): 2489-2513.

109. Onaran, Ö., Stockhammer, E., \& Grafl, L. (2011). Financialisation, income distribution and aggregate demand in the USA. Cambridge Journal of Economics, 35(4): 637-661.

110. Palley, T. I. (1994). Debt, aggregate demand, and the business cycle: An analysis in the spirit of Kaldor and Minsky. Journal of Post Keynesian Economics, 16(3): 371-390.

111. Palley, T. I. (2002). Economic contradictions coming home to roost? Does the U.S. economy face long-term aggregate demand generation problem? Journal of Post Keynesian Economics, 25 (1): 9-32.

112. Palley, T. I. (2007). Financialization: What it is and Why it Matters. PERI Working Paper No. 153.

113. Palley, T. I. (2010a). America's exhausted paradigm: macroeconomic causes of the financial crisis and great recession. New School Economic Review, 4(1): 15-43.

114. Palley, T. I. (2010b). The limits of Minsky's financial instability hypothesis as an explanation of the crisis. Monthly Review, 61(11). Retrieved from https://monthlyreview.org/2010/04/01/ the-limits-of-minskys-financial-instability-hypothesis-as-an-explanation-of-the-crisis/.

115. Palma, J. G. (2009). The revenge of the market on the rentiers. Why neo-liberal reports of the end of history turned out to be premature. Cambridge Journal of Economics, 33(4): 829-869.

116. Panitch, L., \& Konings, M. (2009). Myths of neoliberal deregulation. New Left Review, 57: 67-83.

117. Pérez, C. (2009). The double bubble at the turn of the century: technological roots and structural implications. Cambridge Journal of Economics, 33(4): 779-805.

118. Piketty, T. (2014). Capital in the Twenty-First Century. Cambridge (MA): Belknap Press.

119. Potts, N. (2011). Marx and the crisis. Capitol Eु Class, 35(3): 455-473.

120. Rajan, R. G. (2010). Fault lines: how hidden fractures still threaten the world economy. Princeton: Princeton University Press.

121. Reinhart, C., \& Rogoff, K. S. (2010). Growth in a Time of Debt. NBER Working Paper No. 15639.

122. Roháč, D. (2011, May 17). Does inequality matter? London: Adam Smith Institute.

123. Rosser, J. B. (2003). A Nobel Prize for Asymmetric Information: The economic contributions of George Akerlof, Michael Spence and Joseph Stiglitz. Review of Political Economy, 15(1): 3-21. 
124. Rothschild, M., \& Stiglitz, J. E. (1976). Equilibrium in Competitive Insurance Markets: An Essay on the Economics of Imperfect Information. Quarterly Journal of Economics, 90(4): 629-649.

125. Roubini, N. (2011, October 13). The instability of inequality. Project Syndicate. Retrieved from https:// www.project-syndicate.org/commentary/the-instability-of-inequality?barrier=accessreg.

126. Rowthorn, R. (1980). Capitalism, Conflict E̊ Inflation. London: Lawrence and Wishart.

127. Rowthorn, R. (1981). Demand, Real Wages and Economic Growth. London: Thames Polytechnic. Reprinted in Studi Economici (1982), 18: 3-54.

128. Russo, A. (2012). From the neoliberal crisis to a new path of development. MPRA Working Paper 38004. Economy, 25(3): 496-511.

129. Setterfield, M. (2010). Real Wages, Aggregate Demand, and the Macroeconomic Travails of the US Economy: Diagnosis and Prognosis. Trinity College Department of Economics Working Paper 10-05.

130. Setterfield, M. (2011). Anticipations of the crisis: on the similarities between post-Keynesian Economics and Regulation Theory. Revue de la régulation, 10(2).

131. Shaikh, A. (1978). An introduction to the history of crisis theories. In Union for Radical Political Economics (Ed.), US Capitalism in Crisis (pp. 219-241). New York: U.R.P.E.

132. Shaikh, A. (2011). The first great depression of the 21st century. Socialist Register, 47: 44-63.

133. Shiller, R. J. (2000). Irrational exuberance. Princeton: Princeton University Press.

134. Shleifer, A. (2000). Inefficient Markets: An Introduction to Behavioral Finance. New York: Oxford University Press.

135. Sismondi, J. C. L. (1827). Nouveaux principes d'économie politique, ou de la Richesse dans ses rapports avec la population. Paris: Delaunay Libraire.

136. Stiglitz, J. E. (1992). Capital markets and economic fluctuations in capitalist economies. European Economic Review, 36(2-3): 269-306.

137. Stiglitz, J. E. (2000). Capital market liberalization, economic growth, and instability. World Development, 28(6): 1075-1086

138. Stiglitz, J. E. (2002). Information and the change in the paradigm in economics. American Economic Review, 92 (3): 460-501.

139. Stiglitz, J. E. (2009). The global crisis, social protection and jobs. International Labour Review, 148(1-2): 1-13.

140. Stiglitz, J. E. (2011). Rethinking macroeconomics: What failed, and how to repair it. Journal of the European Economic Association, 9(4): 591-645.

141. Stiglitz, J. E. (2012). The price of inequality. Penguin Books: London

142. Stockhammer, E. (2004). Financialisation and the slowdown of accumulation. Cambridge Journal of Economics, 28(5): 719-741.

143. Stockhammer, E. (2005-6). Shareholder value orientation and the investment-profit puzzle. Journal of Post Keynesian Economics, 28(2): 193-215.

144. Stockhammer, E. (2008). Some stylized facts on the finance-dominated accumulation regime. Competition Eु Change, $12(2): 184-202$.

145. Stockhammer, E. (2015a). Determinants of the wage share: a panel analysis of advanced and developing economies. British Journal of Industrial Relations. doi:10.1111/bjir.12165. 
146. Stockhammer, E. (2015b). Rising Inequality as a cause of the present crisis. Cambridge Journal of Economics, 39(3): 935-958.

147. Sweezy, P. M. (1942). The theory of capitalist development: principles of Marxian political economy. New York: Oxford University Press.

148. Taylor, J. B. (2009). Economic Policy and the financial crisis: an empirical analysis of what went wrong. Critical Review, $21(2-3): 341-364$.

149. Tornell, A., Westermann, F., \& Martínez, L. (2004). The positive link between financial liberalization, growth, and crises. NBER Working Paper 10293.

150. Sau, L. (2013). Instability and Crisis in Financial Complex Systems. Review of Political Tregenna, F. (2009). The fat years: the structure and profitability of the US banking sector in the pre-crisis period. Cambridge Journal of Economics, 33(4): 609-632.

151. van Treeck, T. (2009a). A synthetic, stock-flow consistent macroeconomic model of 'financialisation.' Cambridge Journal of Economics, 33(3):467-493.

152. van Treeck, T. (2009b). The macroeconomics of 'financialisation' and the deeper origins of the crisis. IMK Working Paper No. 9/2009.

153. van Treeck, T. (2014). Did inequality cause the U.S. financial crisis? Journal of Economic Surveys, 28(3): 421-448.

154. van Treeck, T., \& Sturn, S. (2012). Income inequality as a cause of the Great Recession? A survey of current debates. ILO Conditions of Work and Employment Series No. 39.

155. Vázquez, F., \& Federico, P. (2015). Bank funding structures and risk: Evidence from the global financial crisis. Journal of Banking \&ु Finance, 61: 1-14.

156. Vercelli, A. (2011). A Perspective on Minsky Moments: Revisiting the Core of the Financial Instability Hypothesis. Review of Political Economy, 23(1): 49-67.

157. Wade, R. (2009). From global imbalances to global reorganisations. Cambridge Journal of Economics, 33(4): 539-562.

158. White, L. J. (2009). The credit rating agencies and the subprime debacle. Critical Review, 21 (2-3): 389-399.

159. Wray, L. R. (1990). Money and Credit in Capitalist Economies: The Endogenous Money Approach. Adlershot: Edward Elgar.

160. Wray, L. R. (2008). Lessons from the subprime meltdown. Challenge, 51 (2): 40-68.

161. Wray, L. R. (2009). The rise and fall of money manager capitalism: a Minskian approach. Cambridge Journal of Economics, 33(4): 807-828. 